\title{
The Loyalty Determinant Attributes of Store Brands in Food and Grocery in Indian Retailing-An Empirical Study in Twin Cities of Hyderabad
}

\author{
Tirthala Naga Sai Kumar, Prof.M. Ravindar Reddy (Guide), \\ Research Scholar, School Of Management,NIT Warangal. \\ School Of Management, NIT Warangal \\ National Institute Of Technology Warangal Andhra Pradesh India
}

\begin{abstract}
This paper which is an exploratory study, focuses on the important factors responsible for enhancing the customer perceptions about store brands in food and grocery sector in the twin cities of Hyderabad, India. The customer perceptions associated with store brand quality, value and retailer's response towards customers feelings would boost the regular purchase attitude of the well satisfied consumers. Understanding the customers and evaluating the customers' impressions about the store and the store brands is a continuous process which in turn produce fruitful results to the retailers. This paper identifies the critical dimensions of store brand purchase intention in food \&grocery in Indian retailing context.
\end{abstract}

Key Words: Store Brands, Consumer Perceptions, Purchase Intention,Food \& Grocery, Consumer Consciousness

\section{Introduction:}

The current economic environment encourages Indian retailers to be more innovative in their retail efforts to formulate most effective and competitive retail strategies to address the ever changing needs and purchase situations and purchase behavior and, thus, increase the profitability through the timely introduction of essential store brands in food and grocery in Indian retailing sector. It is crystal clear that the retailers are relying more on private label brands to take advantage of local resources and bridge the gap in their product mix and targeting the most specific needs of food and grocery retail consumers in India.the ever expanding urbanization and colonization at the outskirts of the metrocities spread across the red carpet of opportunities in front of the most enthusiastic retailers who are in continuous search for the retail opportunities and development by understanding and addressing the needs and wants of the modern retail customers in India.

The private labels include low quality generics,medium quality private labels,some what less expensive but comparable quality private labels,and finally the premium quality private labels that are priced higher than the national brands.In the past ,the research in retailing was focused on store brand perceived quality,perceived value price,convenience ,store image,and promotipn aspects to improve the purchase intentions of the buyers. The different socio-economic stusus characteristics,personal characteristics, different demographic and environmental factors make the prediction of store brand purchase behavior and purchase predispositions a more complex and ever dynamic phenomina(Agarwal \&Mehrothra;Mittal \&Mittal;Montaner \&Martinez; Whelan\&Davies;Baltar;Omar).Thus there exists a need to re-assess the factors that influence the fast selling of the private labels in food and grocery, in the developing nations like India.the earlier conception about the private label brands was that the price determined the quality .the higher the price, the higher the quality and similarly the lower the price, the lower the quality. The words cheaper and higher prices of private label brands are relative to the prices of national brands.

The retail market was 19\% in 2010(Justin Beneke)on the average all over the globe. The primary target of retailers of store brands was the lower income groups of consumers(Nielsen,2006)The high perceived high quality aspects associated with national brands attracted the confidence of the rich class segment of customers.(Rusch,2002).In India about 30\%of total retail sales comprises only the private label brands.

\section{The Objectives Of The Study:}

1.To assess and analyze the factors that influence the success of the store brands in food and grocery sector in retailing.

2.To explore and identify the factors that affect the retailers to prefer the store brands to the manufacturer brands in food and grocery. 
3.To find out the effect of the socio-economic and demographic attributes on store brand purchase intention and to suggest the curative measures and modality for better performance of private label brands in food and grocery sector.

\section{Review Of Literature:}

The earlier studies focused on the repeat purchases of consumers which indicated the success of store brands(Odin,1999)and the brand loyalty with unique value concept(Holbrook,2001) indicated the success of the store brands.the quality parameters were found to be the success factors based on which the private labels were categorized(Allawadi,2004). The higher price indicates the higher quality and the lower price indicates the lower quality of the private label which are targeted on the rich and the lower income group customers respectively.However a different copy cat concept of "me too"private label brand was observed as the success factor of store brands (SteenKamp,2007).

The past study,however,was confined to quality,price,place,and promotion aspects to explain the store brand re-purchase attitudes of consumers.But the constant and continuous maintenance of these factors is very difficult in the face of the ever changing competitive environments like technology change,political stability and changing economic equations between nations.The recent break up of Wal-Mart(USA) and Bharthi(INDIA) companies tie-up in India indicates these significant changes in the global market(CNN IBN REPORT,2013). The different perceptions about store brands is due to the heterogeneous preferences, the extent of usage,and experienced based consumption,differential needs,perceived quality,value,risk and uniqueness of these store brands by different categories of consumer groups(DelVeccio;Dick,Jain,Robinson;Livesey,Lennon).The appropriate role of store brands in retail strategies assures the consumer confidence and mutual trust(Horowitz;Harcar).The store brands are thus designed strategically to compete with national brand products very effectively. Thus, the propensity of regular purchase of store brands is mainly due to the favorable attitude of consumers toward those products(Binninger;Dick,Jain,Richardson).

The various marketing activities such as product quality,price,promotion,added services and values influence the consumer purchase intention for store brands(Schroder\& Ossel ,Wulf; Dodds, Monroe\& Grewal).The impact of familiarity with store brands on consumer purchase intention was found (Richardson,Jain,Dick) and the extrinsic cues, usage perceived value were the most crucial factors in influencing the purchase of store brands. The consumer involvement in lines with familiarity would help the store brand purchase decision making quickly and increase and purchase action(Miquel\&Manzano)

The consumer consciousness with respect to value, price and budget and discount factors were also found to influence purchase action of store brands(Kara et al.).The previous purchase experience and perception after usage and consumption have impact on store brand purchase decision making. Thus, private label brands have significant role in retail strategy making process. They have important strategic role for retailers(Harcar,Kara,Kucukemiroglu;Burt;Horowitz).

\section{Methodology}

This study was conducted in two phases.In the first stage, an exploratory study

Which was qualitative in nature was carried out to identify the factors affecting the store brand purchase behavior.The exploratory interviews with store managers ,incharges and extensive discussions with academicians,scholars helped us to identify the factorsThe perceived value for money, the product features with respect to quality,price, and the perceived risk with respect to functioning and performance, the retailer reputation in society,and discounts,and other kinds of promotional schemes besides demographics and changing life styles have their impact on purchase intentions of buyers. The extensive literature survey supported the findings and also enables researchers to identify the likely effects of personal satisfaction from the different consumer segments.

In the second stage,a non-experimental survey method(Mall intercept approach)was adopted for collecting the data by interviewing the respondents from various super markets andshopping malls like Big Baaar,Reliance super,More,Vishal ,Spencers,Food bazaar malls in the twin cities of Hyderabad.The exploratory factor analysis,correlations,chi square tests ,percentages would be applied to the data using spss 16.0

A total of 375 respondents were with the questionnaire but only 316 response sheets were found to be appropriate for the data analysis, and the rest were found to be incomplete or unreturned.

\section{ANALYSIS:}

1. Do you believe that the provision for store brand credit cards have impact up on purchase intentions of store brands? 
Table no1.1:The impact study of store brand credit cards on purchase intentions of store brands.

\begin{tabular}{|c|c|c|c|c|c|c|}
\hline Store & $\begin{array}{l}\text { Strongly } \\
\text { Agree }\end{array}$ & Agree & $\begin{array}{c}\text { Neither } \\
\text { agree nor } \\
\text { disagree }\end{array}$ & Disagree & $\begin{array}{l}\text { Strongly } \\
\text { Disagree }\end{array}$ & Total \\
\hline Big Bazaar & $\begin{array}{l}11 \\
42\end{array}$ & $\begin{array}{l}6 \\
8\end{array}$ & $\begin{array}{l}1 \\
1\end{array}$ & $\begin{array}{l}0 \\
3\end{array}$ & $\begin{array}{l}1 \\
0\end{array}$ & $\begin{array}{r}19 \\
54\end{array}$ \\
\hline Reliance & 38 & 5 & 4 & 2 & 1 & 50 \\
\hline More & $\begin{array}{l}34 \\
44\end{array}$ & $\begin{array}{l}16 \\
10\end{array}$ & $\begin{array}{r}11 \\
8\end{array}$ & $\begin{array}{l}9 \\
8\end{array}$ & $\begin{array}{l}3 \\
4\end{array}$ & $\begin{array}{l}73 \\
74\end{array}$ \\
\hline $\begin{array}{l}\text { Spencers } \\
\text { Vishaal } \\
\text { Others }\end{array}$ & 29 & 10 & 2 & 1 & 4 & 46 \\
\hline Total & 198 & 55 & 27 & 23 & 13 & 316 \\
\hline
\end{tabular}

\begin{tabular}{|l|c|r|r|}
\hline \multicolumn{1}{|c|}{ Chi-Square Tests } \\
& Value & df & $\begin{array}{c}\text { Asymp. } \\
\text { Sig. (2- } \\
\text { sided) }\end{array}$ \\
\hline $\begin{array}{l}\text { Pearson } \\
\text { Chi-Square } \\
\text { Likelihood } \\
\text { Ratio } \\
\text { Linear-by- }\end{array}$ & 33.971 & 20 & .026 \\
$\begin{array}{l}\text { Linear } \\
\text { Association } \\
\text { N of Valid } \\
\text { Cases }\end{array}$ & 5.573 & 20 & .009 \\
\hline
\end{tabular}

\section{HYPOTHESIS:}

$\mathrm{H}_{0}$ :The provision for store brand credit cards have no impact up on the purchase intention of store brands. $\mathrm{H}_{1}$ :The provision for store brand credit cards have impact up on the purchase intention of store brands. The $\chi^{2}$ calculated value is 33.971 which is more than $\chi^{2}$ table value(31.41), and hence the null hypothesis is rejected and the alternative hypothesis is accepted,at $\alpha=5 \%$ and $p=0.026$ which is less than $\alpha$ value.

2.Do you agree that the consumer's open choice of selecting items under combo offers with in permissible limits has impact on the purchase intentions of store brands?

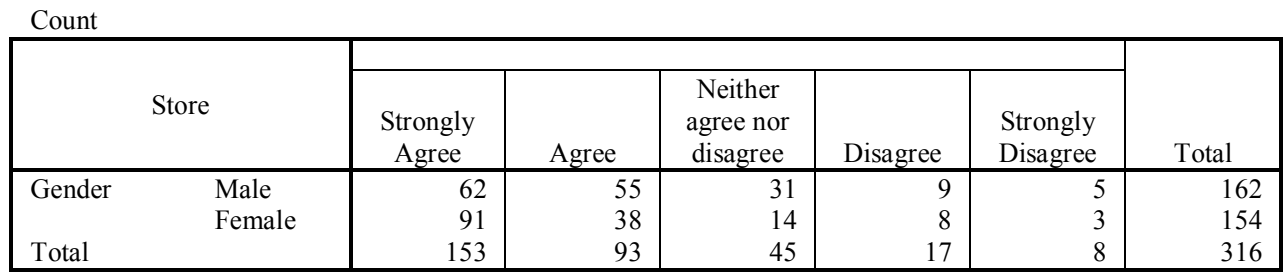

\begin{tabular}{|c|c|c|c|}
\hline \multicolumn{4}{|c|}{ Chi-Square Tests } \\
\hline & Value & $\mathrm{df}$ & $\begin{array}{l}\text { Asymp. } \\
\text { Sig. (2- } \\
\text { sided) }\end{array}$ \\
\hline $\begin{array}{l}\text { Pearson Chi- } \\
\text { Square }\end{array}$ & 15.393 & 4 & .004 \\
\hline $\begin{array}{l}\text { Likelihood } \\
\text { Ratio }\end{array}$ & 15.601 & 4 & .004 \\
\hline $\begin{array}{l}\text { Linear-by- } \\
\text { Linear } \\
\text { Association } \\
\mathrm{N} \text { of Valid } \\
\text { Cases }\end{array}$ & 9.230 & 1 & .002 \\
\hline
\end{tabular}

Table no.1.2:The impact study of consumers free choice to select their preferred items under the combo offers on purchase intentions of store brands.

HYPOTHESIS: 
$\mathrm{H}_{0}$ :The consumers open choice to select their preferred items under combo offers with in permissible limts has no impact up on the purchase intention of store brands.

$\mathrm{H}_{2}$ : The consumers open choice to select their preferred items under combo offers with in permissible limts has impact up on the purchase intention of store brands.

The $\chi^{2}$ calculated value is 15.393 which is more than $\chi^{2}$ table value(9.48), and hence the null hypothesis is rejected and the alternative hypothesis is accepted,at $\alpha=5 \%$ and $p=0.04$ which is less than $\alpha$ value.

3.Do you think that the rationalization of various sub-brands in to most frequently purchased items has influence up on purchase intentions of store brands?

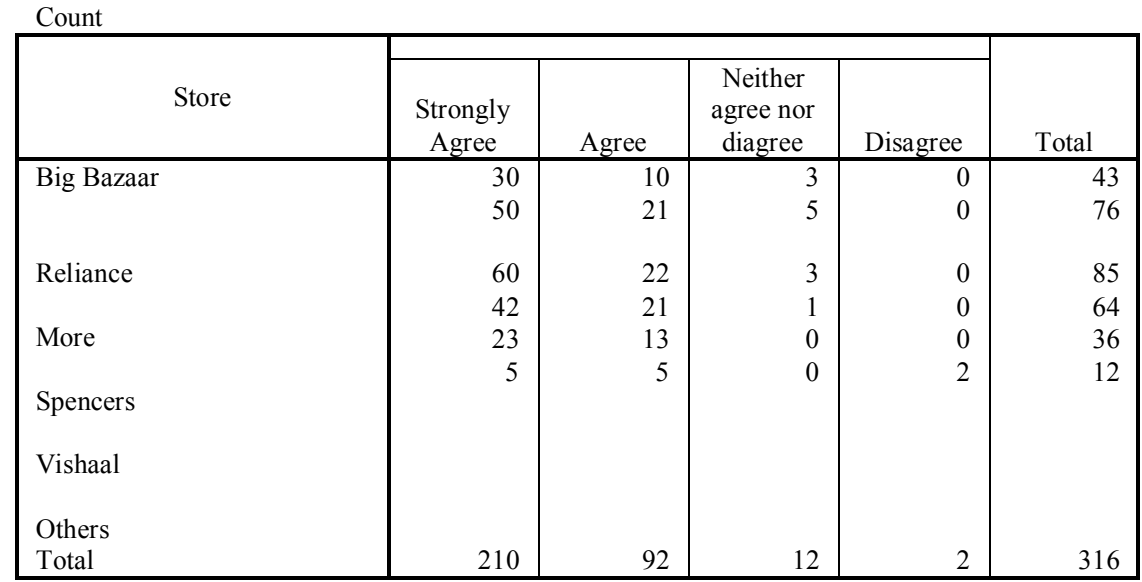

\begin{tabular}{|c|c|c|c|}
\hline \multicolumn{4}{|c|}{ Chi-Square Tests } \\
\hline & Value & $\mathrm{df}$ & $\begin{array}{l}\text { Asymp. } \\
\text { Sig. (2- } \\
\text { sided) }\end{array}$ \\
\hline $\begin{array}{l}\text { Pearson } \\
\text { Chi-Square }\end{array}$ & 59.911 & 15 & .000 \\
\hline $\begin{array}{l}\text { Likelihood } \\
\text { Ratio }\end{array}$ & 23.969 & 15 & .066 \\
\hline $\begin{array}{l}\text { Linear-by- } \\
\text { Linear } \\
\text { Association }\end{array}$ & 1.155 & 1 & .283 \\
\hline $\begin{array}{l}\mathrm{N} \text { of Valid } \\
\text { Cases }\end{array}$ & 316 & & \\
\hline
\end{tabular}

Table no.1.3:The impact study of of rationalization of various sub brands into a few most frequently purchased items on purchase intentions of store brands.

HYPOTHESIS:

$\mathrm{H}_{0}$ :The rationalization of various sub brands in to most frequently purchased items has no impact up on the purchase intention of store brands.

$\mathrm{H}_{3}$ : The rationalization of various sub brands in to most frequently purchased items has impact up on the purchase intention of store brands.

The $\chi^{2}$ calculated value is 59.9 which is more than $\chi^{2}$ table value(24.94), and hence the null hypothesis is rejected and the alternative hypothesis is accepted, at $\alpha=5 \%$ and $\mathrm{p}=0.00$ which is less than $\alpha$ value.

4.Do you agree that the time to perceive the price differentials meant for comparison between store brands and national brands has impact on purchase intentions of store brands? 


\begin{tabular}{|c|c|c|c|}
\hline Store & $\begin{array}{l}\text { Strongly } \\
\text { Agree }\end{array}$ & Agree & Total \\
\hline Big Bazaar & 43 & 0 & 43 \\
\hline Reliance & 76 & 0 & 76 \\
\hline More & 85 & 0 & 85 \\
\hline Spencers & 64 & 0 & 64 \\
\hline Vishaal & 34 & 2 & 36 \\
\hline Others & 11 & 1 & 12 \\
\hline Total & 313 & 3 & 316 \\
\hline
\end{tabular}

\begin{tabular}{|c|c|c|c|}
\hline \multicolumn{4}{|c|}{ Chi-Square Tests } \\
\hline & Value & Df & $\begin{array}{l}\text { Asymp. } \\
\text { Sig. (2- } \\
\text { sided) }\end{array}$ \\
\hline $\begin{array}{l}\text { Pearson Chi- } \\
\text { Square }\end{array}$ & 17.649 & 5 & .003 \\
\hline $\begin{array}{l}\text { Likelihood } \\
\text { Ratio }\end{array}$ & 11.582 & 5 & .041 \\
\hline $\begin{array}{l}\text { Linear-by- } \\
\text { Linear }\end{array}$ & 8.967 & 1 & .003 \\
\hline $\begin{array}{l}\mathrm{N} \text { of Valid } \\
\text { Cases }\end{array}$ & 316 & & \\
\hline
\end{tabular}

Table1.4: The impact study of the time to perceive the price differentials meant for comparison between store brands and national brands has impact on purchase intentions of store brands.

\section{HYPOTHESIS:}

$\mathrm{H}_{0}$ :The time to perceive the price differentials meant for comparison between store brands and national brands has no impact up on the purchase intention of store brands.

$\mathrm{H}_{4}$ : The time to perceive the price differentials meant for comparison between store brands and national brands has impact up on the purchase intention of store brands.

The $\chi^{2}$ calculated value is 17.649 which is more than $\chi^{2}$ table value(11.07), and hence the null hypothesis is rejected and the alternative hypothesis is accepted,at $\alpha=5 \%$ and $\mathrm{p}=0.03$ which is less than $\alpha$ value.

5.Do you agree that the same MRP as that of national brands to the store brands followed by heavy discount offers have impact on the purchase intentions of store brands?

Crosstab

\begin{tabular}{|l|r|r|r|r|}
\multicolumn{1}{c|}{ Count } & \multicolumn{2}{c|}{} \\
\cline { 2 - 5 } \multicolumn{1}{c|}{ Store } & \multicolumn{1}{|c|}{$\begin{array}{c}\text { Neither } \\
\text { Agrongly }\end{array}$} & Agree & $\begin{array}{c}\text { agree nor } \\
\text { diagree }\end{array}$ & Total \\
\hline Big Bazaar & 36 & 4 & 3 & 43 \\
Reliance & 74 & 2 & 0 & 76 \\
More & 80 & 5 & 0 & 85 \\
Spencers & 62 & 2 & 0 & 64 \\
Vishaal & 35 & 1 & 0 & 36 \\
Others & 10 & 2 & 0 & 12 \\
Total & 297 & 16 & 3 & 316 \\
\hline
\end{tabular}

Chi-Square Tests

\begin{tabular}{|l|r|r|r|}
\hline & Value & df & \multicolumn{1}{|c|}{$\begin{array}{c}\text { Asymp. } \\
\text { Sig. (2- } \\
\text { sided) }\end{array}$} \\
\hline $\begin{array}{l}\text { Pearson Chi- } \\
\text { Square }\end{array}$ & 26.427 & 10 & .003 \\
Likelihood & 18.188 & 10 & .052 \\
$\begin{array}{l}\text { Ratio } \\
\text { Linear-by- }\end{array}$ & 3.403 & 1 & .065 \\
$\begin{array}{l}\text { Linear } \\
\text { Association }\end{array}$ & & & \\
$\begin{array}{l}\text { N of Valid } \\
\text { Cases }\end{array}$ & 316 & & \\
\hline
\end{tabular}


Table1.5:The impact study of the strategy that the same MRP as that of national brands to the store brands followed by heavy discount offers has impact on the purchase intentions of store brands.

\section{HYPOTHESIS:}

$\mathrm{H}_{0}$ : The strategy that the same MRP as that of national brands to the store brands followed by heavy discount offers has no impact on the purchase intentions of store brands.

$\mathrm{H}_{5}$ : The strategy that the same MRP as that of national brands to the store brands followed by heavy discount offers has impact on the purchase intentions of store brands.

The $\chi^{2}$ calculated value is 26.427 which is more than $\chi^{2}$ table value(18.30), and hence the null hypothesis is rejected and the alternative hypothesis is accepted, at $\alpha=5 \%$ and $p=0.03$ which is less than $\alpha$ value.

\section{Discussion And Implications:}

The study indicates that the consumers feelings,opinions and behavior, regarding the store retailers strategies and his offerings ,form the basis for the key areas to be touched by the retailers .They still feel that their exercising power on the grounds of their freedom aspects was restricted in the store purchase situations. The buyers reaction to the various retailers strategies and offers, was either not properly analyzed by the retailers or ignored completely or partially. So there seems to be an urgent need to cater to the opinions of the consumers in retailing in India,in particular as most Indians are emotional cum analytical buyers.

The research findings shed the light up on the factors that emerge from the buyer's black box, influence the purchase decision more significantly the that in neighborhood and convenience stores. The study contributes to the retailing literature in food and grocery by being unique and more distinctive one in providing the empirical considerations during the shopping periods.

The findings help the retailers in adapting the changing customers buying styles in the ever changing shopping planet to suit to the best practiced strategies in the retailing business world. These factors have far reaching implications for retail store managers to better evaluate the criteria in food and grocery sector. The findings increase the shoppers delight and thus visiting store frequency with friends and families. Thus the findings highlight the shopping experience aspects with respect to customers which in turn re-enhance the customer loyalty and thus the profitability base of the retailers.

The retailers today have their active attention on catching the eye of the customers and bringing them to the store but they are forgetting the post-visit psychological factors that drive the customers back again,if not met effectively. The present study in food and grocery retailing though has ephemeral but exemplary effects for improving the customer relationships through enhanced synergy approach for mutual benefits to cost ratio. These results show tremendous response in favor of store image as well.

\section{Conclusions:}

The findings of the present study will effectively heighten the performance standards of the retailers and augment the sales volume of the store brands in food and grocery. It contributes to the better understanding of the modern shoppers in the light of recent competitive FDI bill passed by the Indian parliament inviting the retail giant forces of the world like Wal-Mart, Tesco and others. The study examines five important factors and their relationship with purchase intentions of the buyers. It is found that the provision for store brand credit cards has a direct and positive relationship on purchasing store brands, as it would not let the buyers to postpone their buying decisions. The buyers otherwise postpone it, due to the lack of immediate financial provisions. Thus it is observed that the higher the opportunity to avail the provision of store brand credit cards, the higher the purchase intention and immediate purchase actions.

The second factor is that the consumer's open choice of selecting items under combo offers, within permissible limits has impact on the purchase intentions of store brands. The customer craves for freedom to choose items depending on his requirements rather than the pressure exerted by the retailer by imposing his own preferences to add the items to include in the combo offers. The permissible limits include however the price range, store brand varieties etc. The freedom to select customers own preference needs will drive away the fear of buying unnecessary items along with necessities in the combo offers and losing money on such purchases. This strategy in fact delights the customers to revisit and buy even more store brands.

The findings also reveal that the rationalization of various sub-brands in to the most frequently purchased items has influence up on purchase intentions of store brands. This relieves the customers from anxiety and confusion caused by the large number of sub brands in identifying the differences in quality and value for money. The easy identification of quality and value aspects with respect to the store brands by rationalization would help the shoppers in sound decision making in buying the store brands with high levels of confidence.

It is clear from the findings that the time to perceive the price differentials meant for comparison between store brands and national brands has impact up on the purchase intention of store brands. The common 
man does not spend much time in comparing the store brand and national brand at every shelf. So the retailer should exhibit these price advantages in percentages, benefits in kind etc. using the strategy of selective attention. This reduces the time to perceive the differences lying between store brand and national brand. This will help in improving the sales of store brands more effectively.

The last but not the least factor is that the price advantage perception by customers which increases if the MRP of store brand is same as that of national brands but the store brands are further followed by heavy discount offers. This strategy has positive impact on the purchase intentions of store brands. It in fact makes the people perceive the store brand as identical in quality aspects w.r.t. national brands and also reduces the time to make mental calculations separately for store brand and national brand . Thus the customers would be activated by the easy perception process.

\section{Limitations Of The Study:}

As the present research is a beginning point in a new dimension in understanding the impact of factors responsible for purchase intentions of consumers in food and grocery store brands, it has been limited for the cities of Hyderabad district ,particularly, Secunderabad and ,Hyderabad and Greater Hyderabad areas only.The sample size is limited to only 316 respondents from the cities.This research being part of the main research, is presently confined to the select cities only and it will be extended to other cities in future to represent as much subjects as possible to represent the whole population. The present study can be useful researchers in longitudinal research aspects in future. The study can be useful in understanding the purchase behavior of customers of Kirana stores and convenience and super markets and it is useful in studying the customers in other categories of private label brands like non-food and grocery sections of shopping malls as well.

\section{References:}

[1] AllawadiK,Keller K(2004).Understanding retail branding:conceptual insights and research priorities,J. retailing80:331-342

[2] Huang G,Alex SL,Tsang,Nan hou,JAF(2006)."Impact of situational factors on buying decisions in shopping malls",Europian Journal of Marketing,40(1),pp17-43

[3] Mitchel VW(1998)."A Role of consumer risk perceptions in grocery retailing",British Food Journal

[4] Outi uusitalo(2001)."consumer perceptions Of grocery retail formats and brands",Int.Journal of Retail and Distribution management29(5);214-225.

[5] Richardson P,Jain A, Dick A(1996).The influence of store aestheticson evaluation of private label brands,J.Product Brand manage.5(1):19-28

[6] Planet retail. (2008).Private Label Trends World Wide.Presentation delivered in Mumbai,India by Paul Martin,Global Sales Manager

[7] Rusch
York; (2002).Private $/ /$ www.brandchannel.comfeatures effect.asp?pf id=94.Dated 6 May.

[8] Sinha Piyush kumar(2003)"Shopping orientation in the evolving Indian Market”,Vikalpa,28(2),pp13-22

[9] Sridhar .G(2007.,"consumer involvement in product choice:role of perceived risk",Decision,34(2),pp51-66 